\title{
Effectiveness of Poverty Reduction Program with Value Added Creation in Agribusiness Sector and Formulation of Strategic Plan and Policies
}

\author{
Tien Yustini ${ }^{1}$ \\ ${ }^{1}$ Management Department of STIM AMKOP Palembang, Indonesia \\ Correspondence: Priyono, Graduate Program Master of Management, Universitas of Bina Darma, Palembang, \\ Indonesia. Tel: 81-21-697-4878. E-mail: priyono.unu_sidoarjo@yahoo.com
}

Received: January 19, 2018

Accepted: February 14, 2018

Online Published: February 28, 2018

doi:10.5539/ijef.v10n4p51

URL: https://doi.org/10.5539/ijef.v10n4p51

\begin{abstract}
The purpose of this study is to formulate value creation models for agribusiness development to address rural poverty issues and analyze and design a Strategic (policy) model that should be developed for poverty alleviation in South Sumatra.

The object of this study was conducted in Palembang City and Ogan Ilir Regency which identified the poor still relatively big. To measure the effectiveness of poverty alleviation programs that have been done by the government, conducted descriptive qualitative and quantitative analysis. Qualitative analysis is done by describing poverty alleviation programs that have been done, continued and will be done by the government together with other stakeholders. Further analyzed the problems or obstacles encountered in the implementation, formulation and develop a model of community empowerment that is considered effective enough to overcome poverty. The effectiveness analysis is calculated by comparing the planned targets with the results achieved.

From the model formulated and built it is expected to obtain strategies and policies that can be taken by the government to overcome the problems of poverty both in the city and in the countryside.
\end{abstract}

Keywords: poverty, reduction, creation, agribussiness

\section{Introduction}

Indonesia is an agrarian country, but the economy is still low in Indonesia, especially in the village, it all causes poverty. Poverty is caused by uncertain community work. Most villagers work as laborers and farmers with low incomes. Farming communities are categorized as poor because the farming community has many limitations such as knowledge and technology. Poverty is one of the barriers to the well-being of rural people, for which the village community must work together to improve economic development and the government should be sensitive to the problems of poverty that still occur in the community. Rural is an area that is always synonymous with poverty and backwardness. Poverty and backwardness are not because the village is poor and backward but more due to the wrong policy.

Poor households in villages play a major role in the process of poverty reduction. Household is defined as one economic unit and production center. Based on the BPS poverty profile, in March 2016 poverty in Indonesia reached 28.01 million people or 10.86 percent of the total population of Indonesia, although in terms of the number of rural poverty declines, but the percentage of the poor increased. In March 2015 the percentage of poor rural population was 14.21 percent, then decreased in September 2015 to 14.09 percent then rose 0.02 percent in March 2016 to 14.11 percent. When referring to the declining Farmer Stock Exchange (NTP) data - from 102.55 in January 2016 to 101.47 in June 2016 - it is only natural that the percentage of rural poverty increases, as agriculture has declined.

"Therefore, we stated that the index of poverty depth and rural poverty severity index in rural areas in one year is increasing," said Henry Saragih, Chairman of Indonesian Farmers Union (SPI). The index of rural poverty depth in March 2015 is 2.55 or lower than March 2016 of 2.74.

There are very important documented reports in directing government policies and programs towards poverty alleviation during the transition to democracy. A common issue in this report is the differences in various 
interpretations of poverty within the scope of government (Everett, 2003). Therefore, the new role of Regional Government as mandated includes: job creation, increased economic growth and poverty reduction in its territory (Oldfield \& Parnel, 1998). This new role includes prioritizing basic needs and advancing community development. In this dispensation the authority of local government is to take the stage and play an important role, which cannot be legally hindered or compromised by the provincial or national government (Bekker \& Leide, 2003). There have been two distinct transitional stages of Regional Government since 1994. This phase includes: (a) the transition period from 1995 to 2000 and (b) the establishment of a complete City in December 2000 (Ntsebeza, 2003). The latter part is characterized by the depiction of new city limits and the incorporation of many urban rural cities. In this phase too, cities were reduced from 834 in 1995 to 284 in 2000 and this was followed by a reduction in the number of board members (Cousins \& Kepe, 2004). The period between 1995 and 2000 witnessed a number of problems stemming from institutional change, lack of experience with democracy, lack of trust and skill (Cousins \& Kepe, 2004). According to Manor (2000), most of the newly created municipalities are experiencing poverty, especially the former hometowns with a very small income base and unfunded mandates for poverty reduction and service delivery. Newly created local municipalities do not differ greatly from local communities

South Sumatra as one of the richest provinces in Indonesia also has poverty problems. It is ironic that under the development of South Sumatra there are still some areas where the majority of the population is poor. In September 2016 the number of poor people (population with per capita expenditure per month below the Poverty Line) in South Sumatera Province reached 1,096 .500 people (13.39 percent). Reduced by 4,690 people compared to March 2016 of 1,101,190 (13.54 percent Percentage of the urban poor in March 2016 of 12.74 per cent fell to 12.73 per cent by September 2016. While the percentage of poor people in rural areas down from 13.99 percent in March 2016 to 13.77 percent in September 2016. During the period of March 2016-September 2016 the poor in urban areas rose by 3.35 thousand people (from 374.53 thousand people in March 2016 to 377 , 88 thousand people in September 2016), while in rural areas dropped by 8.05 thousand people (from 726.67 thousand people in March 2016 to 718,62 thousand people in September 2016.

Table 1. Poverty Depth Index (P1) and Index, Poverty Severity (P2) in South Sumatra by Region, September 2015 - September 2016

\begin{tabular}{cccc}
\hline Details & Urban & Rural areas & Urban + Rural areas \\
\hline (1) & $(2)$ & $(3)$ & $(4)$ \\
Poverty Depth Index $(\boldsymbol{P 1})$ & & & \\
\hline September 2015 & 1,681 & 2,312 & 2,087 \\
March 2016 & 1,788 & 2,143 & 2,015 \\
September 2016 & 1.889 & 1.995 & 1.957 \\
Poverty Severity Index (P2) & & & \\
September 2015 & 0,382 & 0,554 & 0,493 \\
March 2016 & 0,365 & 0,458 & 0,425 \\
September 2016 & 0,468 & 0,488 & 0,481 \\
\hline
\end{tabular}

Source: BPS Province South Sumatera, processed from Susenas data September 2015, March 2016 and September 2016.

Target groups include subsistence-based households, beneficiaries of land distribution programs. At the end of 2007, 3,000 CASP projects were under way, with an estimated 230,000 beneficiaries. In total, the land redistribution program is well defined and well-funded but statistics show that only $5 \%$ of the commercial farming land has been moved (Tregurtha et al., 2010). Targeting poverty alleviation is the main goal of multiple programs. Communities selected for this development initiative are properly screened to ensure that they are in fact related to inadequate physical infrastructure (Coleman, 2001) Overall receipt of few social benefits by recipients has resulted in the government raising funds from 2.9 million in 1994 to 13, 4 million in April 2009 (Leibbrandt, 2006; Woolard et al., 2010). In the economic spectrum, grant payments and other allowance forms targeted at disadvantage levels increased from $2.9 \%$ of GDP by $4.4 \%$, which is three times more than the average expenditure of 1.4\% of GDP in these countries. (Leibbrandt et al., 2010).

The problem of poverty is not just the number and percentage of the poor. Another dimension to note is the depth and severity of poverty. In addition to being able to minimize the number of poor people, poverty policy also must reduce the depth and severity of poverty. The Poverty Severity Index for the period of March 2016 September 2016 increased from 0.425 in March 2016 to 0.481 in September 2016, but decreased compared to the September 2015 Poverty Severity Index of 0.493 . When compared between urban and rural areas, the 
Poverty Depth Index (P1) and Poverty Severity (P2) Indexes in rural areas are higher than in urban areas. In September 2016, the value of the Poverty Depth Index (P1) for urban areas was 1.889 while in rural areas it was much higher, at 1.995 . Meanwhile Poverty Severity Index Value (P2) for urban is 0,468 whereas in rural area reach 0,488 .

The Agripreneurship Program is required to develop entrepreneurs and management personnel to serve the Agriculture Industry worldwide (Bairwa et al., 2014b). Agripreneurship is strongly influenced mainly by the economic, educational and cultural situation (Singh, 2013). Due to changes in the socio-economic, economic, political, environmental and cultural dimensions of the world, the choice of farmers and nations to survive and to ensure success in changing their economic environment becomes increasingly critical. It should also be noted that the emergence of a free-market economy globally has resulted in the development of a new spirit of " Agripreneurship " and the increasing need of individuals to take responsibility for running their own businesses (Alex, 2011). Entrepreneurship is connected by finding ways and means to create and develop profitable farming businesses. Terms Glossary, entrepreneurship and entrepreneurship are often used in the context of education and small business in agriculture. Dollinger (2003) defines entrepreneurship in agriculture as the creation of innovative economic organizations for the purpose of growth or profit under conditions of risk and uncertainty in agriculture. Gray (2002) on the other hand defines an entrepreneur as an individual who manages a business with a view to developing a business and with the leadership and managerial skills necessary to achieve that goal.Provincial Government South Sumatra continues to reduce the number of poor people, with programs conducted jointly and multi sector. Head of Trade Service of South Sumatra added, it will continue to try to increase export quotas. This effort is done by providing training and intensifying counseling to local business actors. The intensification of government involvement in cooperation with various agencies, he believes, will be able to bring about changes in improving the competitiveness of local businessmen or craftsmen in the midst of the competition in the era of MEA free market.

Based on data from BPS South Sumatra, the number of poorest residents first in the Palembang City of about 203 thousand inhabitants. Secondly, Ogan Komering Ilir (OKI) Regency is about 134 thousand inhabitants, and the lowest poor are in Pagar Alam City with about 12 thousand inhabitants. From the number of PMKS, there are three districts within Ogan Ilir (OI), one of them is in Pemulutan Sub-district.

Therefore, the Department of Social Affairs (Dinsos) OI District Government conducted efforts to educate social welfare issues in the three sub-districts, which were divided into five counseling. The location of social welfare issues was chosen based on the predicted income of every family head (KK) whose value is still within the weak category. Poverty in Indonesia is the main problem that becomes a priority to be searched for through various development programs launched by the government. Most poverty occurs in rural areas. This makes the villagers make various efforts to survive.

The cycle of poverty stems from the fact that total productivity in poor countries or regions is very low as a result of lack of capital, imperfect markets, and economic backwardness. From the demand side it can be explained that the low level of real income causes the level of demand to be low, so in turn the level of investment is also low. Low investment levels lead to less capital and lower productivity as reflected in lower real incomes.

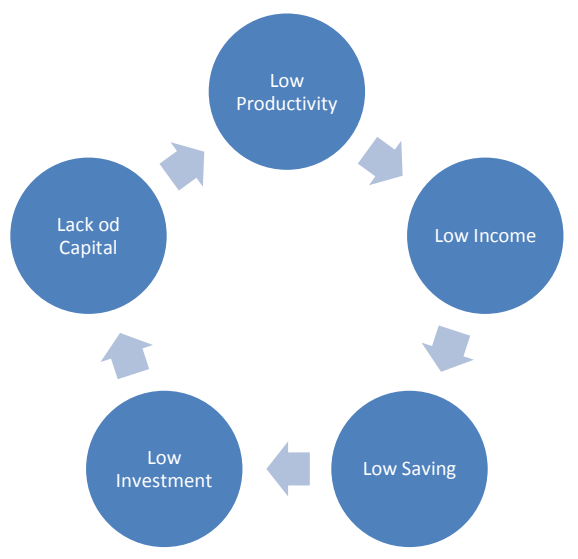

Figure 1. Poverty circle nurkse version

Source: Jhingan, 2004. 
From the supply side, it is illustrated that low income levels reflecting low savings will lead to low investment and limited capital. The other circles are those concerning human backwardness and natural resources. The development of natural resources in an area depends on the ability of human productivity. If the population is backward and illiterate, lacking knowledge and skills, then natural resources will be useless or useless. Conversely the backwardness of natural resources will cause human backwardness.

\section{Research Methodology}

\subsection{The Scope of Research}

This study includes evaluation of poverty alleviation programs in both Palembang and Ogan Ilir districts, identification of constraints faced, formulating models of opportunities and potential agribusiness that can be developed by creating value added to address poverty, the last is formulating a strategy model and policies that can be made to alleviate poverty in South Sumatra in general.

\subsection{Research Sites}

This research was conducted in Palembang City and Ogan Ilir Regency which identified the poor people is still relatively big

\subsection{Object of Research}

The research object is the poor population spread in Palembang city and in Ogan Ilir Regency, besides the potential and opportunities of agribusiness that can be created to overcome the problem of poverty for the urban and rural population.

\subsection{Population and Sample Determination Procedures}

Popualsi in this research is poor people spread in South Sumatera area both in town and in rural, with population of 1,096 people (BPS, Susenas Sept 2016). From the data will be taken by puppossive poor people in the area of Palembang and Ogan Ilir district. To determine the sample used Slovin formula by using alpha $(\alpha=5 \%=0,05)$ obtained sample as follows:

$$
n=\frac{N}{1+N(e)^{2}}=\frac{1,096}{1+1,096(0,05)^{2}}=\frac{1,096}{1+2,74}=1,096 / 3,74
$$

Note. $n=293,05=293$ People.

\subsection{Data Source}

Data sources are obtained from secondary and primary data sources. Secondary data, such as data on the number of poor people in South Sumatra, urban and rural. Secondary data is obtained from official documents or reports or issued by the Central Bureau of Statistics, City and Province, Ministry of Social Affairs, village ministries. Primary data was obtained by distributing structured questionnaires aimed at the sample sample respondents ie the poor people in Palembang city and Ogan Ilir district

\subsection{Analysis Method}

To answer and analyze problem in this research hence used method as follows:

1) To measure the effectiveness of poverty alleviation programs that have been done by the government, qualitative and quantitative descriptive analysis is conducted. Qualitative analysis is done by describing poverty alleviation programs that have been done, continue and will be done by the government together with other stake holders. Further analyzed the problems or obstacles encountered in the implementation, formulate and develop a model of community empowerment that is considered effective enough to overcome poverty. The effectiveness analysis is calculated by comparing the planned targets with the results achieved.

2) From the model formulated and built it is expected to obtain strategies and policies that can be taken by the government to overcome the problem of poverty both in the city and in the countryside. Strategies are analyzed using "SWOT Analysis" which is to formulate a policy by looking at "Strength", analyzing "Weakness" (weakness or deficiency, identifying and reaching opportunities) and finding one method or way to overcome the challenges / challenges faced in efforts to eradicate urban and rural poverty in South Sumatra, particularly Palembang and Ogan Ilir The research framework model is illustrated in the fishbone diagram contained in Appendix 1 (this research proposal).

\subsection{Operational Definition of Variables}

Each of these variables and indicators is described in the operational definition as follows: 
Table 2. Operational definition of variables

\begin{tabular}{|c|c|c|}
\hline Variable & Indicator & Dimension \\
\hline \multirow{18}{*}{$\begin{array}{l}\text { The effectiveness } \\
\text { of Poverty } \\
\text { alleviation } \\
\text { programs }\end{array}$} & \multirow[t]{4}{*}{ Program Goals } & a. $\quad$ Shape / manner \\
\hline & & b. Frequency \\
\hline & & c. Time: \\
\hline & & d. The place \\
\hline & \multirow[t]{2}{*}{ Target process } & a. Goal directly \\
\hline & & b. Goals are not immediate \\
\hline & Program resources & $\begin{array}{l}\text { Human Resources includes amounts based on } \\
\text { population duties and training adjustments }\end{array}$ \\
\hline & \multirow[t]{5}{*}{ Communication } & $\begin{array}{l}\text { a. Supporting Resources include number and } \\
\text { completeness of species }\end{array}$ \\
\hline & & b. Between implementers (escort):Covers \\
\hline & & frequency, formal and informal \\
\hline & & formfollow-up and suggestions \\
\hline & & $\begin{array}{l}\text { c. External with Program participants include } \\
\text { frequency of form, and action }\end{array}$ \\
\hline & \multirow[t]{2}{*}{ Characteristics of the Program Implementing Agency } & $\begin{array}{l}\text { a. The organizational structure of the Program } \\
\text { implementer }\end{array}$ \\
\hline & & b. Key tasks and Companion Functions \\
\hline & \multirow[t]{3}{*}{ Socio-economic and cultural conditions } & a. Social conditions \\
\hline & & b. Economic conditions \\
\hline & & c. Cultural conditions \\
\hline & Disposition of the implementer & Understanding of Program Companion \\
\hline Value added & $\begin{array}{l}\text { The added value that can be created from the creation of new } \\
\text { activities / jobs from the development / processing of } \\
\text { agricultural products }\end{array}$ & $\begin{array}{l}\text { The creation of new jobs by creating } \\
\text { entrepreneurshipb. Added work time allocationc. } \\
\text { Increased productivityd. Increased revenue }\end{array}$ \\
\hline \multirow[t]{2}{*}{ Agribusiness } & $\begin{array}{l}\text { Any business that is closely related to the processing system } \\
\text { and production activities in the agricultural sector which } \\
\text { includes the management production of agriculture itself as } \\
\text { well as the management of production } \\
\text { (http://www.pengertianuruturutaraara.net/pengertian-agribisnis- }\end{array}$ & $\begin{array}{l}\text { a. Processing systems and activities } \\
\text { b. Production management } \\
\text { c. Management of agricultural products }\end{array}$ \\
\hline & pertanian/) & \\
\hline \multirow[t]{2}{*}{ Renstra } & $\begin{array}{l}\text { Strategic planning is an effort to implement three important } \\
\text { steps: Firstly identify trends, threats, and opportunities, where } \\
\text { results may change historical trends. Second, improve } \\
\text { organizational performance driven by competitive conditions. } \\
\text { Third, compare each work unit within the organization to } \\
\text { develop development priorities by allocating strategic resources } \\
\text { based on the prospects of each work unit (Salusu: 2004). }\end{array}$ & \\
\hline & $\begin{array}{ll} & \text { Policy } \\
\end{array}$ & \\
\hline \multirow[t]{4}{*}{ Poverty } & Basic rights fulfillment & $\begin{array}{l}\text { a. Limited employment opportunities and } \\
\text { businesses } \\
\text { b. Limited Access to Education } \\
\text { c. Limited Health Service Access } \\
\text { d. Limited Food Sufficiency and Quality }\end{array}$ \\
\hline & Social Factors Culture & $\begin{array}{l}\text { a. Mindset of mental attitude and motivation to get } \\
\text { out of poverty; } \\
\text { b. Not able to interact socially; } \\
\text { c. Low motivation and tend to slack and not } \\
\text { optimal participation of women in the family; } \\
\text { d. The lack of community participation. }\end{array}$ \\
\hline & Regional infrastructure & $\begin{array}{l}\text { a. Lack of smooth / destructive transportation } \\
\text { infrastructure } \\
\text { b. Place isolated and the absence of clean water }\end{array}$ \\
\hline & Degradation of Natural Resources and the Environment & $\begin{array}{l}\text { a. Floods and other disasters; } \\
\text { b. Damage of land due to exploitation of natural } \\
\text { resources; The contamination of rivers and beaches }\end{array}$ \\
\hline
\end{tabular}




\begin{tabular}{cll}
\hline Variable & Indicator & Dimension \\
\hline South Sumatra & Scintillating is an expression intended to describe the province & a. Education, \\
Scintillating & of South Sumatra which is experiencing rapid development in & b. Health services \\
& all areas within the area. & c. Means of transportation, \\
& http://ala-ma2d.blogspot.co.id/2013/04/siap-menuju-sumatera-s & d. Sports and tourism \\
& elatan-gemilang.html & e. Economi \\
& & f. Social \\
\hline
\end{tabular}

\section{Result}

\subsection{Analysis of Problems of Agribusiness Development to Overcome the Problem of Rural Poverty}

Agricultural Development is still considered the most important of the overall economic development, especially since this agricultural sector became the savior of the national economy because it is actually growing, while other sectors are negative growth. Some of the reasons underlying the importance of agriculture.

a. The potential of large and diverse resources,

b. The share of national income is quite large,

c. The size of the population that depends on the sector and

d. Become the basis of growth in the countryside

The large agricultural potential, but most of the many farmers belonging to the poor are very ironic in South Sumatra. This indicates that the government is not only less empowering farmers but the whole agricultural sector. On the other hand, an increase in investment in agriculture made by PMA and PMDN-oriented export-oriented investors is generally capital-intensive and has little role in the absorption of labor or creates more labor. This is coupled with the fact that the strong accessibility to large foreign/private investors compared to small farmers in the utilization of agricultural resources in Indonesia, it is considered necessary grand strategy of agricultural development through empowering small farmers. Through these conceptions, it is hoped to be able to grow the agricultural sector, which in turn is able to become a new source of growth for the South Sumatra economy, especially in terms of achieving targets: farmers welfare, providing food, as a means of equitable distribution of development to overcome income disparities between communities as well as intra, is an input market for agro-industry development, generating foreign exchange, providing jobs, increasing national income, and retaining resource sustainability.

The potential of agribusiness in South Sumatra is in the formation of Gross Regional Domestic Product, agribusiness sector is the biggest value added contributor in the national economy, estimated at $45 \%$ of total value added. The agriculture sector is the sector that absorbs the largest workforce estimated at $74 \%$ of the total absorption of the national workforce. Agribusiness sector also plays a role in the provision of community food. Success in meeting the basic needs of rice has played a strategic role in the creation of national food security which is closely related to socio security, economic stability, political stability, and security or national security. Agribusiness activities are generally resource based industry. There is not a single country in the world like Indonesia that is rich and diverse natural agricultural resources (endowment factor). The fact has shown that in the international market only resource-based industries have comparative advantages and contribute to the largest exports, hence the development of agribusiness in Indonesia further ensures more competitive trade. Agribusiness activities have great forward and backward linkage. Agribusiness activities (with the magnitude of future and backward linkages) if the impact is calculated based on the direct and indirect multiplier impacts on the foreseeable economy will be enormous. In the era of globalization, consumer appetite for food consumption is predicted to change into fast food and the market for agricultural production is also predicted to shift from traditional market to Kentucky model. Thus agro-industry will become the most attractive business activity. Agribusiness technology is very flexible that can be developed in capital-intensive or labor-intensive, from simple to advanced management, from small to large scale. So that South Sumatra is very populous and crowded, then in its development is made possible by various business segments. From the result of the research on 293 samples in Palembang and Ogan Ilir district, we get the following sample characteristics: 
Table 3. Characteristics of respondents in Palembang and Ogan Ilir district as gender

\begin{tabular}{lccc}
\hline Gender & Palembang & Ogan Ilir & Total \\
\hline Man & 116 & 73 & 189 \\
Women & 34 & 70 & 104 \\
Amount & $\mathbf{1 5 0}$ & $\mathbf{1 4 3}$ & $\mathbf{2 9 3}$ \\
\hline
\end{tabular}

Source: research results, 2017.

Based on table 1. Above about 189 peasants $(64.5 \%)$ are men, the rest are women (104.5\%). Furthermore, the average farmer as shown in table 2, was about 26 - 49 years old $(66.9 \%)$. This means that the average farmer who is the respondent of this research is very productive, but the question is why the level of productivity and their income is still low.

Table 4. Characteristics of respondents in Palembang and Ogan Ilir district by age level

\begin{tabular}{lccc}
\hline Age Level & Palembang & Ogan Ilir & Total \\
\hline$<25$ & 7 & 19 & 26 \\
$26-49$ & 89 & 107 & 196 \\
$>50$ year & 54 & 17 & 71 \\
Amount & $\mathbf{1 5 0}$ & $\mathbf{1 4 3}$ & $\mathbf{2 9 3}$ \\
\hline
\end{tabular}

Source: research results, 2017.

Viewed from the income level, the sample farmers were classified based on the average income level as in the following table.

Table 5. Average farmer's revenue rate

\begin{tabular}{ccccc}
\hline No & $\begin{array}{c}\text { Group of Sample Farmers } \\
\text { by Level of income (\%) }\end{array}$ & $\begin{array}{c}\text { Number of Cumulative } \\
\text { Farmer Sample }\end{array}$ & $\begin{array}{c}\text { Total Cumulative Income } \\
\text { Farmer sample (IDR.) }\end{array}$ & $\begin{array}{c}\text { \% Cumulative Income } \\
\text { Farmer sample (\%) }\end{array}$ \\
\hline 1 & 40\% Lowest Revenue & 197 & 118.353 .700 & 20,69 \\
2 & 40\% Intermediate Income & 73 & 218.115 .900 & 38,13 \\
3 & 20\% Highest Revenue & 23 & 235.534 .450 & 41,18 \\
& Amount & $\mathbf{2 9 3}$ & $\mathbf{5 7 2 . 0 0 4 . 0 5 0}$ & $\mathbf{1 0 0}$ \\
\hline
\end{tabular}

Source: processed from Primary data, 2017.

From the table above shows that almost $3 / 4$ sample farmers have average revenues ranging from IDR 1,952,232.25 per month, and the results showed that 197 samples or about 67.24 percent of farmers are in the lowest income level that is cumulatively amounted to IDR $118,353,700$ a year. The rest is in the $40 \%$ middle income group of 73 farmers and the rest only 23 sample farmers who are in the $20 \%$ high income group. This indicates that the average sample farmer is at the poverty level. The biggest problem faced by farmers when going to develop agribusiness-based agribusiness systems and agroindustry can be seen in the following table:

Table 6. Level of problem analysis agricultural system development based on Agribusiness

\begin{tabular}{lcccc}
\hline \multicolumn{1}{c}{ Identification of problems } & Palembang & Ogan Ilir & Total & \% \\
\hline 1. Production sustainability & 14 & 17 & 31 & 10,57 \\
2. Inadequate market & 15 & 10 & 25 & 8,52 \\
3. The length of the marketing channel & 12 & 14 & 26 & 8,82 \\
4. Low bargaining power & 23 & 16 & 39 & 13,31 \\
5. Price flutuatiion & 33 & 17 & 50 & 17,06 \\
6. lack of market information & 22 & 20 & 42 & 14,43 \\
7. lack of claraty of information network & 15 & 28 & 43 & 14,68 \\
8. poor quality of prodution & 7 & 12 & 19 & 6,47 \\
9. The low quality of human resources & 9 & 9 & 18 & 6,14 \\
Amount & $\mathbf{1 5 0}$ & $\mathbf{1 4 3}$ & $\mathbf{2 9 3}$ & $\mathbf{1 0 0}$ \\
\hline
\end{tabular}

Source: research results, 2017. 
The table above shows that most of the problems in the development of agribusiness based farming system at farmer's level is the fluctuation of the price of agricultural products $(17.06 \%)$, the uncertain price especially when the harvest arrives where there is a decrease in the price of agricultural produce makes the farmer always in weak condition. The price of agricultural production always fluctuates depending on the changes that occur on demand and supply. Rise and fall of prices can occur in the short term that is per month, per week even per day or can also occur in the long term. For rapidly damaged agricultural commodities such as vegetables and fruits, the effects of changing market demand are sometimes so striking that the prevailing prices change rapidly. It can be observed different market price changes in the morning, afternoon and evening. At the time of the season of abundant products low prices, otherwise at the time of the season did not rise drastically. This situation makes it difficult for farmers to undertake production planning, as well as traders difficult to estimate demand.

In addition, the lack of clarity of marketing networks (14.68\%) in which Manufacturers and / or traders from regions find it difficult to penetrate existing marketing networks in other regions because the parties involved in the marketing network and where the activities are taking place are unknown. In addition, it is not known also the rules that apply in the system. This causes the resulting production to experience barriers in terms of network marketing expansion. In general an existing marketing network between producers and traders has an agreement that forms a strong bond. The agreement is an unwritten secret that is difficult to know by others.

The lack of market information (14.43\%) also triggered the difficulty of agribusiness development in rural areas. Market information is the determining factor of what is produced, where, why, how, and for whom the product is sold at its best. Therefore, appropriate market information can reduce business risk so that traders can operate with low marketing margins and provide benefits for the traders themselves, producers and consumers. Limitations of market information related to the location of remote farming, knowledge and ability to analyze the data is still lacking and so forth. In addition, the low level of formal education of the community, especially farmers, causes the ability to digest or analyze information sources is very limited. These conditions led to farming done without going through careful planning. Similarly, traders do not know the market condition well, especially macro conditions.

The development of her agribusiness must be supported by strong capital. Without strong capital it is impossible for agribusiness to flourish. An organization is required to assist farmers in developing their agribusiness potential and market potential from their agricultural products. Cooperatives are considered be container in overcoming problems that exist in farmers. Agribusiness-based cooperatives should be able to support the development of agribusiness subsystems (trading of agricultural inputs, farming activities, cultivation, support services), providers of market information for members, to apply agricultural technology, and the main actors of agro-industry activities.

\subsection{Strategy Model (Policy) Development of Agribusiness Enterprises to Address the Problem of Farmer Poverty}

The poor are characterized by low levels of education so knowledge and insight are very limited; including to the control of productive assets, especially land cultivation and capital is very limited, so rely on life with energy; other than that the physical condition of housing is very apprehensive; and limited facilities and infrastructure (transportation, telecommunications and information). Not only is the health condition of the family concerned, and the pattern of household expenditure is dominated for food, especially staple food. The poverty reduction program must be done with empowerment, which is how to help the poor families themselves to be able to eradicate themselves and their families from poverty independently and sustainably. In the context of the empowerment of the poor, poverty alleviation can be accomplished by improving education, practical training, employment and striving, production technical assistance, capital assistance, and helping to access the market. Efforts to strengthen and expand the economic network of the people or poor communities will provide opportunities for families and their members to develop themselves as opportunities and options available to achieve prosperity and independence. The empowerment model for poverty alleviation offered in this research is: 


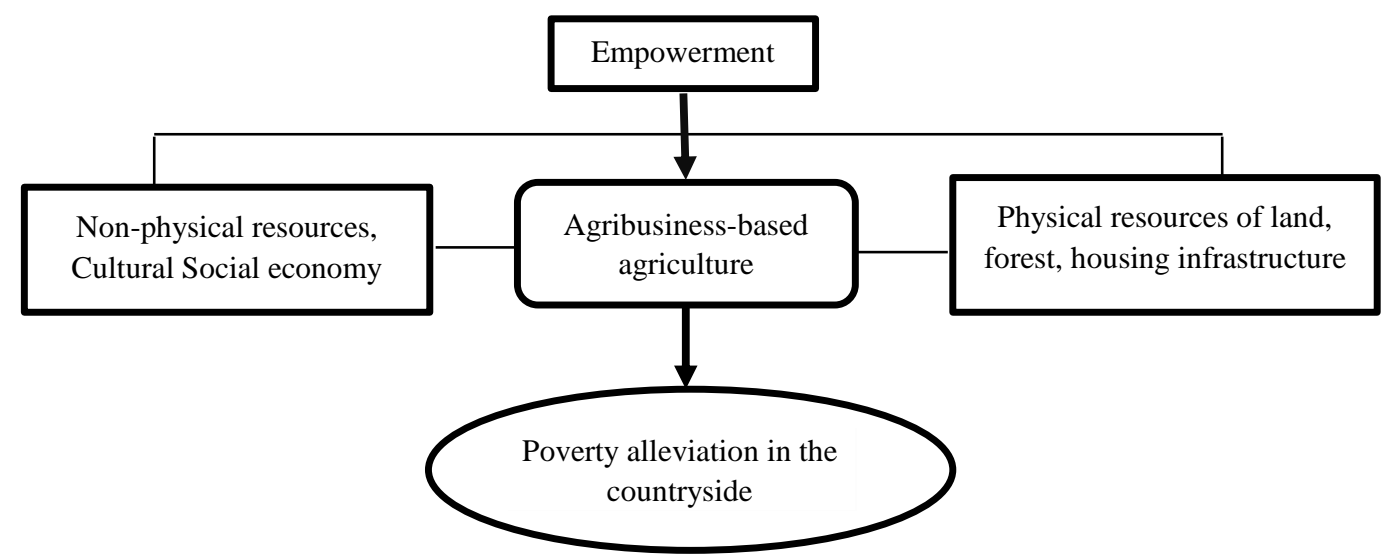

Figure 2. Model of empowerment for poverty alleviation in rural areas

Therefore, there needs to be an integration between institutions in the districts / municipalities up to the village level, namely: between non-political institutional institutions, economic institutions-the business / private sector and community institutions. Government institutions, how government policies and programs can be directed to empowering the people's economy, so that many people can have access and control over local resources and natural economic systems conducive to the growth and development of productive economic enterprises for the poor. Meanwhile, community institutions are aimed at strengthening socio-economic institutions of growing and developing societies. In addition to these three institutions, can function as catalysts and facilitators of the implementation of community economic development.

Short-term strategies that need to be done early on are identifying poverty issues; assessing the potential of both natural resources, human resources, technology and institutions that exist; identifying key constraints and problems in poverty reduction both technical, economic, and institutional constraints; identify poverty alleviation policies and programs of the three existing institutions; coordinate and synchronize inter-agency programs or related government agencies either vertically or horizontally; there needs to be consistency between programs / activities with budget allocations; the division of roles between the three institutions; determine the target group and formulate the planning, implementation, and conduct of a participatory development program.

The long-term strategy establishing the Corruption Eradication Commission in an area that brings together three inter-related institutions; undertake a joint study of poverty issues in the region and the review of poverty reduction policies; and formulate, plan and implement long-term programs, so that the program is sustainable and succeeds in empowering the poor to become an advanced, productive, and independent community.

Listening to the above two patterns of approaches, it takes a method or step of working together that is able to answer both short and long term strategies. The steps taken are then directed into the following five main strategies: Visionary leadership; coordination of bureaucratic work units; Development of new innovation systems for poor communities; Development of productive economic enterprises based on the potential of the poor; and Development of service units in the region up to the remote villages. Capacity building and human resource competencies in both leadership, institutional implementers, and program targets are vital, as it will determine the success of poverty reduction programs in the regions. Through the integration of elements of leadership, implementers and target groups, it is expected that the poor can produce high productivity and with good quality. Thus the products produced by this group can be integrated into the market economy system, both local, regional and global markets.

Despite the many people's economic development programs and the empowerment of the poor, the poverty hazard still plagues the lives of the poor. Poverty is one of the conditions of underdevelopment that indicated the existence of symptoms of quality of human life (community) that is far from adequate measured from the needs of normal life. The problem of backwardness shown by the still high poverty in various regions of Indonesia is in line with the claim of development success, embracing economic growth and macroeconomic stability. Choice of empowerment strategy for poor community group is still done, among others, Community-based economic development based on local institutions; Development of people's agriculture with industrial culture; Development of local raw materials based agroindustry; and Development of appropriate and location-specific technologies, as well as Capital provision through microcredit programs for the development of productive economic enterprises specifically targeting the poor. 
Provide some alternative strategies that can be considered for empowering the poor, including a strategy that is directed directly to cover the symptom of the powerlessness of society, such as overcoming the symptoms of lack of food and nutrition with appropriate food material empowerment worth cheap and free; the production strategy, which is a strategy directed to produce own food (such as: rice or corn); Economic strategy is a strategy directed to improve local resource-based economic activities in a region; The Agro ecosystem Improvement Strategy is a strategy directed to improve the condition of agro ecosystem that is damaged and unhealthy; Socio-Cultural Strategy is a strategy directed to improve the structure of low-income people in particular and the wider community in a more general sense.

To undertake poverty reduction programs, economic growth and equal employment opportunities are needed simultaneously. With growth, equity and an effective coordination system, it is expected to increase spending on public infrastructure (public social infrastructure). Particularly in the provision of facilities and infrastructure supporting productive economic activities are evenly distributed. In addition, an effective inter-institutional coordination system, either on a national scale or at local or regional level, will transform the poor into productive communities, so that productive economic activities undertaken can produce competitive products. Thus the economy of poor society groups can gradually be integrated into local, regional, and export markets.

\section{Conclusion}

Poverty that many people hit the peasant community quickly and thoroughly must be addressed so as to improve the quality of life of farmers, especially in rural areas. Utilization of strategic rural resources must be mastered so as to improve the quality of human resources. Average poor farmers have relatively low incomes, are less involved in productive activities, have less access and control over resources to increase revenue. This is influenced by, among others, economic, cultural, social, and geographic factors. Farmer empowerment model is needed to enable poor farmers to actively participate in the utilization of rural resources. Strengthening the social economy of poor peasants is the core of farmer empowerment and will be optimal if farmers are given the opportunity to participate in the utilization of rural resources. Community based economic development based on local institutions; The strategy of developing people's agriculture with industrial culture; Development of local raw materials based agroindustry; and The development of appropriate and location-specific technologies, as well as the provision of capital through microcredit programs for the development of productive economic enterprises specifically targeting the poor are a strategy deemed appropriate to address poverty.

\section{References}

Alex, L. (2011). A Review and Analysis of Policies on Farmers' Entrepreneurship Development. A publication of PELUM, Misereor, pp. 1-55.

Bairwa, S. L., \& Kushwaha, S. (2012). Agro Industry scenario in India. In S. P. Singh (Ed.), Agricultural research and Sustainable development in India (pp 159-182). Bharti Publications, New Delhi.

Bairwa, S. L., Kushwaha, S., Meena, L. K., Lakra, K., \& Kumar, P. (2014b). Agribusiness Management Education: A Review on Employment Opportunities. International Journal of Scientific and Research Publications (IJSRP), 4(2), 1-4.

Bairwa, S. L., Kushwaha, S., Meena, L. K., Lakra, K., \& Kumar, P. (2014a). Agribusiness Potential of North Eastern States: A SWOT Analysis. In Singh et al. (Eds.), Agribusiness Potentials in India: Experience from hill states (pp. 544-556). EBH Publishers (India) Guwahati - New Delhi.

Bekker, S., \& Leilde, A. (2003). Resident's Perceptions of Developmental Local Government: Exit, Voice and Loyalty in South African Towns. Politeia, 22(1), 144-165.

Central Bureau of Statistics. (2010). Total Population of Indonesia and Its Composition. Central Statistics Agency of South Sumatra Province.

Coleman, E. M. (2001). Keynote Address by the Mpumalanga MEC, E.M. Coleman, of the Department of Social Development, at the Mpumalanga Provincial Poverty Summit, 2-3 March. Retrieved from http://www.info.gov.za/speeches/2001/0103051145a1002.htm

Cousins, B., \& Kepe, T. (2004). Decentralisation when Land and Resource Rights are Deeply Contested. $\begin{array}{lllll}\text { European Journal of Development } & \text { Research, } & \text { 16(1), }\end{array}$ http://dx.doi.org/10.1080/09578810410001688725

Dollinger, M. J. (2003). Entrepreneurship - Strategies and Resources. New Jersey: Pearson International Edition.

Everatt, D. (2003). The Politics of Poverty. In D. Everatt, \& V. Maphai (Eds.), The real state of the nation: South 
Africa after 1990 (pp. 75-100). Development Update Special Edition 4.

Gray, C. (2002). Entrepreneurship, Resistance to change and Growth in Small Firms. Journal of Small Business and Enterprise Development, 9(1), 61-72. https://doi.org/10.1108/14626000210419491

Leibbrandt, M., \& Poswell, L. (2006). Measuring Recent Changes in South African Inequality and Poverty Using 1996 and 2001 Census Data. In H. Bhorat, \& R. Kanbur (Eds.), Poverty and Policy in Post-Apartheid South Africa. Pretoria: HSRC Press. http://dx.doi.org/10.1787/5kmms0t7p1 ms-en

Leibbrandt, M., \& Woolard, I. (2010). Trends in South African Income Distribution and Poverty since the Fall of Apartheid. OECD Social, Employment and Migration Working Papers, No. 101, OECD Publishing. https://doi.org/10.1787/5kmms0t7p1ms-en

Manor, J. (2000). Integrated planning and implementation in rural areas: Experiences from Agri-Tourism Spatial Development Initiatives (SDIs). In B. Cousins (Ed.), At the Crossroads. Land and Agrarian Reform in South Africa into the 21st century, Cape Town: Programme for Land and Agrarian Studies, School of Government, University of the Western Cape National Land Committee (pp. 111-28).

Ntsebeza, L. (2003). Local Governance, Power and Natural Resources: A Perspective from the Rural Areas of South Africa's former Bantustans. In Environmental Governance in Africa Working Papers: WP No14.

Oldfield, S., \& Parnel, S. (1998). Developmental Local Government in South Africa: A Handbook for Urban Councilors and community Members. Urban Sector Network

Singh, A. P. (2013) Strategies for Developing Agripreneurship among Farming Community in Uttar Pradesh, India. Academicia: An International Multidisciplinary Research Journal, 3(11), 1-12.

Sugiyono. (2009). Business Research Methods. Alfabeta Bandung.

Tregurtha, N., Vink, N., \& Kirsten, J. (2010). Presidency Fifteen Year Review Project- Review of Agricultural Policies and Support Instruments in South Africa 1994-2009. Trade \& Industry Policy Strategies (TIPS).

\section{Copyrights}

Copyright for this article is retained by the author(s), with first publication rights granted to the journal.

This is an open-access article distributed under the terms and conditions of the Creative Commons Attribution license (http://creativecommons.org/licenses/by/4.0/). 